\title{
How Did the Latest Increase in Fees in England Affect Student Enrolment and Inequality?
}

\author{
Koen Geven
}

\section{Introduction}

The progressive introduction of markets in higher education seems to lead to ever-higher prices for students and their families, at least in the industrialised world. Between 2000 and 2011, the share of private investments in higher education has increased in more than $75 \%$ of OECD countries (OECD 2014). In the United States, for instance, tuition fees for in-state students have risen by $42 \%$ over 10 years, and have more than doubled over the last 20 years to just over $€ 7000$ (US \$ 9139) per year (College Board 2014). Historical data is harder to obtain for Europe, but fees now exist in a majority of countries, with universities usually charging between $€ 1000$ and $€ 5000$ per year (Eurydice 2014). Many countries are considering to introduce fees or to raise existing fees, although there are some notable exceptions. ${ }^{1}$ As tuition fees continue to rise, there is much public anxiety about how these may affect enrolment and inequality. Yet, there is little empirical evidence of how recent fee increases affect student choices, at least in Europe.

Commentators widely agree that higher prices may affect student enrolment and inequality, but opinions differ about the direction of the effect. The debate is divided between what I will call - in simplified terms - 'pessimists' and 'optimists'. 'Pessimists' typically argue that fees may be a risky investment in the students' future. Referring to empirical work on student price responsiveness (Dearden et al. 2011; Heller 1997; Leslie and Brinkman 1987), they expect that higher price could push a substantial group of students off the market. They point out that students from lower social backgrounds can be particularly affected, since the price is higher for them in relative terms. 'Optimists' argue that higher fees (especially in

${ }^{1}$ For instance, all states in Germany have now abolished tuition fees for undergraduate students.

K. Geven $(\bowtie)$

European University Institute, Florence, Italy

e-mail: koen.geven@eui.eu

(C) The Author(s) 2015

A. Curaj et al. (eds.), The European Higher Education Area,

DOI 10.1007/978-3-319-20877-0_31 
combination with student support) may have a (marginally) positive effect on enrolment and inequality (Carneiro and Heckman 2002; Shavit et al. 2007). The higher fee may not be a barrier for access, since the returns to a university degree would still be higher than the new price, and demand far outstrips supply (Becker 1993).

This paper aims to contribute to this debate by analysing the fee increase in English higher education in 2012. A number of papers have investigated the effects of increases in tuition fees in earlier years (Boliver 2011; Dearden et al. 2008) and there have been a few reports on what happened after the 2012 reforms (Orr et al. 2011; UCAS 2012). Until now, however, no article has yet investigated the effects of the most recent changes using a semi-experimental research design, at least to my knowledge. This paper presents a first such analysis by exploiting differences in rules for different groups of students in the United Kingdom. Indeed, only English and students from other European Union countries were faced with the price increase, while all other students (Welsh, Scottish, Northern Irish, International non-EU) were not affected. The research question is "How did the 2012 reforms of university funding affect university enrolments and inequality in England?" This question will be subdivided in four sub-questions, ${ }^{2}$ namely:

1. What is the effect of the 2012 reforms on enrolment in general?

2. What is the effect of the 2012 reforms on enrolment of students in different age groups?

3. What is the effect of the 2012 reforms on enrolment of students from different socio-economic backgrounds?

4. What is the effect of the 2012 reforms on enrolment of students from different ethnic groups?

Beyond the empirical case, this paper contributes to the tradition in the literature on the elasticity of demand for higher education (for an overview, cf. Heller 1997; Kane 2004). Increasingly, researchers are using semi-experimental designs to identify the causal effect of price changes on student enrolment (Dynarski 2003; Hübner 2012). This study aims to make two contributions to this literature: (1) it studies a major price change for a large group of students, whereas previous studies usually analyse small price changes for small groups. (2) it analyses how the price increase has affected inequality, a relation which remains little understood (Kane 2004).

\footnotetext{
${ }^{2}$ It should be noted here, already, that these questions only address one dimension of inequality, namely inequality in access to university, something sociologists refer to as 'vertical inequality' (Gerber and Cheung 2008). The effects on 'horizontal inequality' will be analysed in a separate paper employing a similar research design. The question is then whether students who are studying in a market environment make substantively different choices (for different universities or different subject fields).
} 


\section{The 2012 Reforms}

The 2012 reform involved more than just a hike in tuition fees. The main elements of the reform are (1) universities charge higher tuition fees, (2) public subsidies were redirected to students rather than universities, and (3) regulation on student enrolments was loosened. These reforms happened in parallel, leading to the establishment of a pseudo-market for higher education in England (Ansell 2010; Brown 2013). As a former vice-chancellor of a British university recently stated, "[h]igher education has been privatised right under our noses. And no one is taking any notice". 3 Each of these aspects will be dealt with here in turn. Table 1 also gives a short summary of the policy changes. As good overviews exist of the 2012 reforms (Brown 2013; Chowdry et al. 2012; McGettigan 2013) I will give only the briefest summary of the changes here.

First, the costs of higher education have been steadily passed on from the government to students and their families. ${ }^{4}$ Whereas English students in the late 1990s paid nothing for an entire undergraduate degree, they now pay just over $€ 11,000$ (£9000) per year or close to $€ 34,000(£ 27,000)$ for a typical undergraduate degree. Figure 1 gives an overview of the evolution of the annual costs of studying at university for different groups over the last 10 years.

This figure shows two important variations in fee levels. (a) Fees for English and EU students ${ }^{5}$ have risen in two sharp jumps, namely in 2006/07 and 2012/13. These fee increases were part of two major reforms in English higher education, namely the 2004 Higher Education Act, and the "Browne review" of student finance in 2010. Each of these reforms raised the maximum amount (or 'cap') of money that a university could ask from an undergraduate student. (b) The figure also makes clear that the increases in fees were not spread equally across the regions. In Scotland, fees were gradually abolished, whereas students from Wales and Northern Ireland remain subsidised to keep their tuition fee level at pre-2012 prices. Meanwhile, international (non-EU) students face-more or less-stable prices since 2010.

Secondly, the funding from the government has changed fundamentally. Direct funding for higher education has almost completely dried up. Whereas British universities received $80 \%$ of its funding from the state in 1995 , this was reduced to $30 \%$ by 2011 , the biggest change in any of the OECD countries ${ }^{6}$ (OECD 2014).

\footnotetext{
${ }^{3}$ Roger Brown, Quoted in The Observer, Sunday 12 October 2014. http://www.theguardian.com/ education/2014/oct/12/have-universities-been-privatised-by-stealth.

${ }^{4}$ In the higher education literature, this phenomenon is often referred to as 'cost-sharing'.

${ }^{5}$ Due to European Union legislation, universities cannot discriminate their prices between students from different EU member states. They can, however, discriminate prices between members of the same country. This awkward glitch in legislation have led to the paradoxical situation that allows for the difference-in-differences design.

${ }^{6}$ The OECD average was $69 \%$ in 2011 (i.e. in 2011 the average university in OECD countries received $69 \%$ of its funding from public sources).
} 
Table 1 Overview of policy changes affecting new undergraduate enrolments from the academic year 2012/2013

\begin{tabular}{l|l|l}
\hline Policy area & Pre 2012/13 & Post 2012/13 \\
\hline $\begin{array}{l}\text { Tuition } \\
\text { fees }\end{array}$ & Capped at $£ 3000$ & Capped at $£ 9000$ \\
\hline $\begin{array}{l}\text { Funding to } \\
\text { universities }\end{array}$ & $\begin{array}{l}\text { 'Cost sharing' philosophy -mix of } \\
\text { public and private funding (from } \\
\text { tuition fees and other private } \\
\text { sources) }\end{array}$ & $\begin{array}{l}\text { Mostly private, after cuts to subsidies } \\
\text { to higher education institutions }\end{array}$ \\
\hline $\begin{array}{l}\text { Student } \\
\text { support }\end{array}$ & $\begin{array}{l}\text { Grants for poor students, and } \\
\text { separate loans for tuition fees and } \\
\text { living costs }\end{array}$ & $\begin{array}{l}\text { More generous grants for poor } \\
\text { students, higher loans to compensate } \\
\text { for higher fees, similar loans for living } \\
\text { costs }\end{array}$ \\
\hline $\begin{array}{l}\text { Student } \\
\text { number } \\
\text { controls }\end{array}$ & $\begin{array}{l}\text { Each university is allocated a } \\
\text { maximum number of students to } \\
\text { recruit }\end{array}$ & $\begin{array}{l}\text { Basic number of students is still fixed, } \\
\text { but universities are free to compete for } \\
85,000 \text { student places }\end{array}$ \\
\hline
\end{tabular}

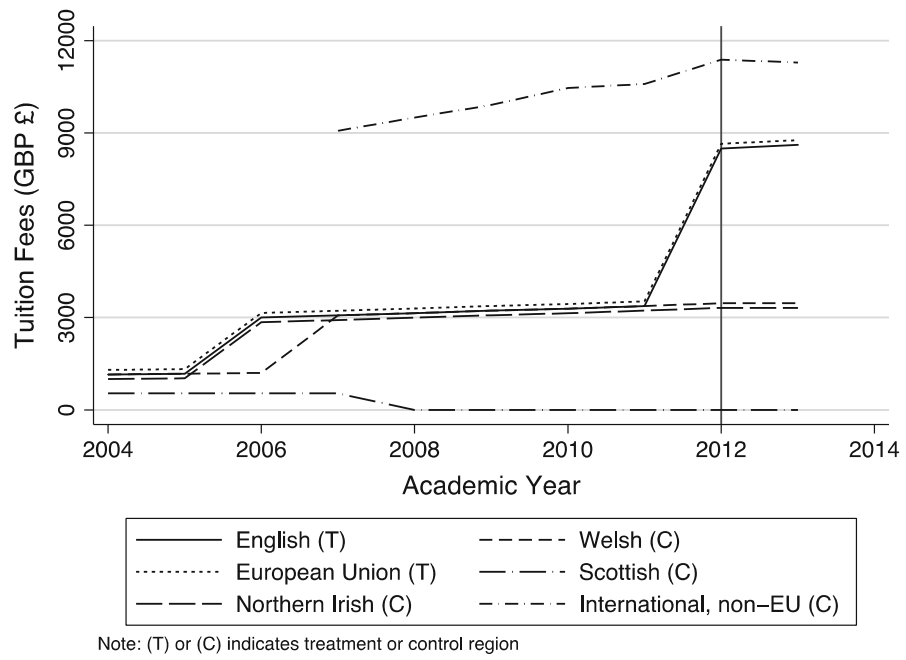

Fig. 1 Evolution of fees in nominal prices (i.e. not corrected for inflation). Note Prices for international students are averages for classroom-based subjects. Sources OFFA, BBC, The Guardian, Reddin survey of tuition fees

In 2012, universities only received $23 \%$ of total income from the government. ${ }^{7}$ The budget for teaching was indeed reduced strongly; the Institute for Fiscal Studies estimated that the reduction was $-86 \%$ (Chowdry et al. 2012, p. 232) leaving little

\footnotetext{
${ }^{7}$ See https://www.hesa.ac.uk/pr201 for the figures on different sources of income of universities in England.
} 
of what was left. Much of this funding has been redirected to the students' loans system, thereby only indirectly providing support to the universities.

Rather than subsidising universities directly, the English government now supports students through a programme of loans and grants. Students can take out a 'tuition fee loan' to pay for their fees. They can also take a 'maintenance loan' to pay for their living costs. These loans have to be repaid to the state after the student stops studying and reaches a certain level of income (currently students pay back $9 \%$ on a yearly income earned above $€ 26,000$ - or $£ 21,000$ ). Students from low-income families are eligible for maintenance grants and scholarships to support their living costs. The Student Loans Company estimates that $87 \%$ of students in England take out a tuition fee loan, and a large majority (84\% of all students taking out loans) take out both a tuition fee loan and a maintenance loan. ${ }^{8}$

Thirdly, the government relaxed the so-called 'student numbers controls' on universities. To allow some sort of control over how much money goes around in the student loans' system, the funding council imposed a maximum number of students that universities could enrol. From 2012/13 universities were allowed to freely recruit students that had a minimum level of demonstrated ability (i.e. grades or qualifications). Universities were completely free to recruit part-time students, whatever their demonstrated ability. Although the number of students for which free recruitment was possible was initially small (estimated at 85,000 students), ${ }^{9}$ this change allowed universities to mount recruitment campaigns in order to catch a larger market share.

In sum, the main elements of the new market in higher education are a (1) a price mechanism, (2) universities are dependent on the student market for their financial survival (through a reduction of public subsidies), and (3) a mechanism linking supply and demand (through relaxing student number controls). Importantly, since each of these elements changed in parallel, there is little sense in estimating the effect of only one of these changes on student enrolment. The next section will ask what theoretical expectations are about the effect of the policy changes on student choices.

\section{Competing Expectations About the Effects of the Reforms}

Earlier theoretical and empirical work holds competing expectations about how the reforms may affect enrolment and inequality. I will outline below why some may expect the reforms to lead to reduced student numbers and to increased inequality (the pessimist view), and why others will expect marketisation to increase student

\footnotetext{
${ }^{8}$ See Statistical First Release 05/2013, published in November 2013. http://www.slc.co.uk/media/ 694170/slcsfr052013.pdf.

${ }^{9}$ Department of Business Innovation and Skills (2011). White Paper: Students at the Heart of the System. London: TSO.
} 
enrolments and to maintain or even decrease inequality (the optimist view). While I will give a simplified account of the complex literature on tuition fees, my goal here is only to show that we may have competing expectations about how fees affect student enrolment.

\subsection{The Pessimists' View: Lower Enrolment and Higher Inequality}

As discussed above, the main element of the 2012 reform is perhaps the change in prices. From the perspective of both classical human capital theory (Becker 1993) and sociological rational action theory (Breen and Goldthorpe 1997) we may expect that higher costs may decrease enrolment and increase inequality. If prices go up, this may present a barrier for the marginal student who may not consider higher education a worthy investment. Everything else being equal, then, we may expect higher prices to lead to lower demand, and thus lower enrolment levels for those affected by higher prices. ${ }^{10}$

There exists a rich body of empirical work on these phenomena, primarily from the United States. Early reviews, such as Leslie and Brinkman's (1987), showed that a substantial increase in prices usually led to a reduction in demand. On average, they found that a price increase of $\$ 100$ led to a reduction in demand of about $0.7 \%$. Subsequent reviews have found slightly smaller price effects, and typically use a $\$ 1000$ price change to estimate demand effects (cf. Dynarski 2003; Kane 1995). A recent study in Canada has found for instance, that an increase in prices of $\$ 1000$ led to a decrease in enrolment between 2.5 and $5 \%$. In the United Kingdom, a price increase of $£ 1000$ has found to reduce enrolment by $3.9 \%$ (Dearden et al. 2011).

With regards to inequality, quite a few studies argue that tuition fee hikes disproportionally affect students from lower social backgrounds. An update to Leslie and Brinkman's study (Heller 1997) argues that students from poor families have a different demand curve. This finding is confirmed in several studies. McPherson and Schapiro (1991) found that low-income white students were more responsive to price changes. Similarly, Coelli (2009) found this to be the case in Canada.

While some credit constraints may be offset by the English student support system, certain students may still be 'risk averse' (Pratt 1964). From the perspective of Rational Action Theory (Breen and Goldthorpe 1997), one can expect that students from lower social classes are more risk averse than students from higher

\footnotetext{
${ }^{10}$ As always, the question is to what extent everything else is really equal. As returns to higher education remain, on average, higher than the costs, it is by no means guaranteed that higher prices will reduce enrolment from this perspective.
} 
status families. This argument has been used to explain why students from lower social classes are diverted away from university in Germany (Hillmert and Jacobs 2003). For higher social strata, the monetary costs of attending university may be offset by the social costs of not attending higher education. In other words, there are many reasons to expect a stronger decrease in enrolment for students from lower social classes.

\subsection{The Optimists' View: Higher Enrolment and Lower Inequality}

There are several serious counter-arguments to be given against the pessimist view. Firstly, how to square ever higher-prices with ever-higher enrolment rates? Time-series data at the macro-level that show an ever increasing rise in college attendance over the last century (cf. Schofer and Meyer 2005). Secondly, why do systems with higher fees also have overall higher enrolment rates than those without fees, and why are such systems typically more inclusive (Shavit et al. 2007)? Finally, why were several empirical studies not able to confirm a higher price responsiveness of students from poor families (prominent examples include Carneiro and James 2002; Ellwood and Kane 2000).

Leslie and Brinkman (1987, p. 200ff), already offered a wide variety of explanations for this phenomenon. Two of these issues may be particularly important for the English case. One important issue seems to be selectivity. Cameron and Heckman (1998) argue that pupils who face the choice of going to university are already positively selected based on (typically unobserved) ability and motivation. Students from low income family (those who "make it against the odds") may be most strongly selected on these traits (Shavit and Blossfeld 1993). Price therefore plays only a marginal role in deciding whether to go to college or not. Students from lower social classes in particular may decide that the price of college is only a minor deterrent.

Indeed, if price plays a role at all, it may be offset with policy measures such as subsidies and loans. Again, Carneiro and Heckman (2002) argue that only very few students face serious liquidity constraints when trying to decide about going to college. These liquidity constrains can easily be addressed by subsidising student loans or providing other forms of state aid to poor families. And indeed, rising tuition is usually accompanied by various policy measures to compensate for higher prices. Governments and universities provide subsidies, fee discounts, loans and other types of students' support to target students from lower social strata. In the United Kingdom, a comprehensive students' loan programme was implemented alongside the tuition fees. For all these reasons, we may not know a priori how the 2012 reforms would affect students. The next sections will try to draw up an answer to this question. 


\section{Research Design}

The 'causal effect' of the marketisation reforms will be presented through a 'difference-in-differences' design. This is a pseudo-experimental research design that has become popular in policy studies following pioneering work by Card and Krueger (1994) in the field of labour economics. The intuition behind these designs is that it is possible to identify a causal effect by comparing trends before and after a policy has been implemented, using another region where that policy has not been implemented as a control group.

The marketisation of universities in the United Kingdom follows just such a pattern. As mentioned earlier, only students from England faced the increase in tuition fees (see Fig. 1), whereas the situation remained unchanged for students from Wales, Scotland, Northern Ireland and for overseas students (non-EU). This situation thus allows for a pseudo-experimental setting, dividing these groups into 'treatment' and 'control' groups, as in Table 2.

Any (semi-) experimental design requires some similarity between treatment and control groups. While comparability is assured in terms of both observable and unobservable characteristics of these groups in randomised trials, this is very

Table 2 Division of regions into 12 treatment and 10 control groups

\begin{tabular}{|c|c|c|}
\hline Academic year domicile & Group & Used for research questions \\
\hline North East England & Treatment & All \\
\hline North West England & Treatment & All \\
\hline Yorkshire and the Humber & Treatment & All \\
\hline East Midlands & Treatment & All \\
\hline West Midlands & Treatment & All \\
\hline East of England & Treatment & All \\
\hline London & Treatment & All \\
\hline South East England & Treatment & All \\
\hline South West England & Treatment & All \\
\hline Wales & Control & All \\
\hline Northern Ireland & Control & All \\
\hline Scotland & Control & All \\
\hline Africa & Control & Only for enrolment, not inequality \\
\hline Asia & Control & Only for enrolment, not inequality \\
\hline Australasia & Control & Only for enrolment, not inequality \\
\hline Middle East & Control & Only for enrolment, not inequality \\
\hline North America & Control & Only for enrolment, not inequality \\
\hline Other Europe & Control & Only for enrolment, not inequality \\
\hline South America & Control & Only for enrolment, not inequality \\
\hline Guernsey, Jersey and the Isle of Man & Treatment & Only for enrolment, not inequality \\
\hline England Unknown & Treatment & Only for enrolment, not inequality \\
\hline Other European Union & Treatment & Only for enrolment, not inequality \\
\hline
\end{tabular}


Table 3 A descriptive overview of the data, pre- and post-treatment

\begin{tabular}{l|l|l|l|l}
\hline & \multicolumn{2}{l}{$\begin{array}{l}\text { Treatment (English and } \\
\text { EU-students) }\end{array}$} & \multicolumn{2}{l}{$\begin{array}{l}\text { Control (Welsh, } \\
\text { Northern Irish, Scottish, } \\
\text { International students) }\end{array}$} \\
\cline { 2 - 5 } & $\begin{array}{l}\text { Pre } \\
(2010 / 11)\end{array}$ & $\begin{array}{l}\text { Post } \\
(2013 / 14)\end{array}$ & $\begin{array}{l}\text { Pre } \\
(2010 / 11)\end{array}$ & $\begin{array}{l}\text { Post } \\
(2013 / 14)\end{array}$ \\
\hline Students (mean per region) & 54,385 & 45,590 & 16,075 & 15,310 \\
\hline Age (mean and standard deviation) & 24.52 & 22.78 & 25.49 & 24.26 \\
\cline { 2 - 5 } & 9.97 & 8.50 & 12.27 & 11.40 \\
\hline Parental social class (UK only) & & & & $41 \%$ \\
\hline Service Class & $43 \%$ & $43 \%$ & $41 \%$ & $41 \%$ \\
\hline Middle Class & $16 \%$ & $16 \%$ & $17 \%$ & $17 \%$ \\
\hline Working Class & $18 \%$ & $20 \%$ & $17 \%$ & $18 \%$ \\
\hline Unemployed & $0 \%$ & $0 \%$ & $0 \%$ & $0 \%$ \\
\hline Unknown/not classified & $23 \%$ & $19 \%$ & $24 \%$ & $23 \%$ \\
\hline Ethnicity (UK only) & & & & $92 \%$ \\
\hline White & $75 \%$ & $73 \%$ & $92 \%$ & $90 \%$ \\
\hline Black or Black British & $8 \%$ & $9 \%$ & $1 \%$ & $2 \%$ \\
\hline $\begin{array}{l}\text { Asian or Asian British } \\
\text { (Indian/Pakistani/Bangladeshi) }\end{array}$ & $7 \%$ & $8 \%$ & $1 \%$ & $1 \%$ \\
\hline Mixed & $3 \%$ & $4 \%$ & $1 \%$ & $1 \%$ \\
\hline Other & $4 \%$ & $4 \%$ & $1 \%$ & $1 \%$ \\
\hline Unknown & $2 \%$ & $2 \%$ & $3 \%$ & $5 \%$ \\
\hline Note Cous & & & $17 \%$ \\
\hline
\end{tabular}

Note Counts rounded to the nearest five to prevent individual identification, percentages rounded to integers. Source Own calculations based on HESA data

unlikely to occur in non-randomised allocation to treatment and control groups. Table 3 presents the means and standard deviations of the observable characteristics of the treatment and control groups in this study. Students are broken down by 'domicile', which is a variable measuring the address of the student before they enrolled at university (i.e. most likely their parental home), and hence defines the eligibility for a certain fee regime. While the table makes clear that the groups are comparable in some respects (particularly, class composition), they are different in other respects (size, age).

The situation presented in Table 3 is quite a typical problem for non-randomised experiments (Angrist and Pishke 2008), and it indicates that it is impossible to identify a 'causal effect' by comparing the post-treatment situation between treatment and control regions. There may be unobserved characteristics for either the treatment or the control regions that influence the choices of students. The solution for this problem is a 'difference-in-differences' design that eliminates this problem of unobserved heterogeneity. Provided that the differences between treatment and control groups are time-invariant, this research design identifies the causal effect (i.e. there are no factors that influence only the treated or only the control groups in the time period that is observed). Below, I will discuss whether it is likely that any time-variant changes affect either the treatment or control groups. 


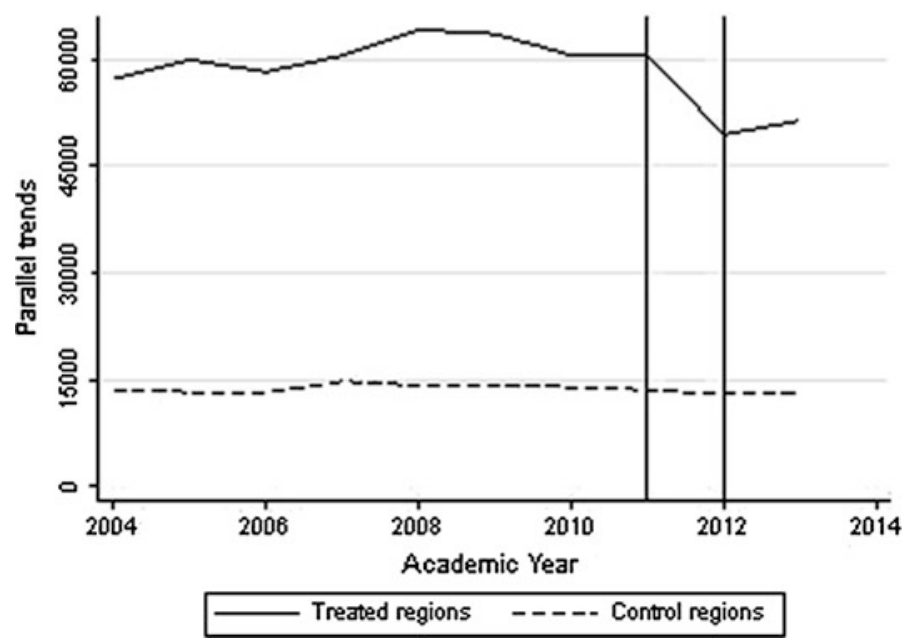

Fig. 2 Parallel trends for undergraduate enrolments in control and treatment regions. The English line represents an average of all English regions. Source Own calculations based on HESA data

The simple idea behind the 'difference-in-differences' strategy is that it takes the difference between the treatment and control groups, before and after the treatment. More formally, the quantity of interest (the causal effect) looks as follows:

$$
\mathrm{E}\left[Y_{1} \mid D=1\right]-\mathrm{E}\left[Y_{1} \mid D=0\right]-\mathrm{E}\left[Y_{0} \mid D=1\right]-\mathrm{E}\left[Y_{0} \mid D=0\right]
$$

where $\mathrm{E}\left[Y_{1} \mid D=1\right]$ is the expected value for the treated group after the treatment, $\mathrm{E}\left[Y_{1} \mid D=0\right]$ is the expected value for the non-treated group after the treatment, $\mathrm{E}\left[Y_{0} \mid D=1\right]$ is the expected value for the treated group before treatment, and $\mathrm{E}\left[Y_{0} \mid D=0\right]$ is the expected value for the non-treated group after the treatment.

\subsection{Pre-treatment Trends}

Figure 2 shows the pre- and post-trend treatments in undergraduate enrolments in the United Kingdom from the academic year 2004/05 until 2013/14. While it is clear that the total amount of students from England is much higher than those from the control groups, the lines do not take a fundamentally different shape before the reform.

\subsection{Stability in Composition}

Secondly, it is hard for students to escape the fee-regime. Figure 3 shows the amount of students who are studying in the UK, but are studying outside their 


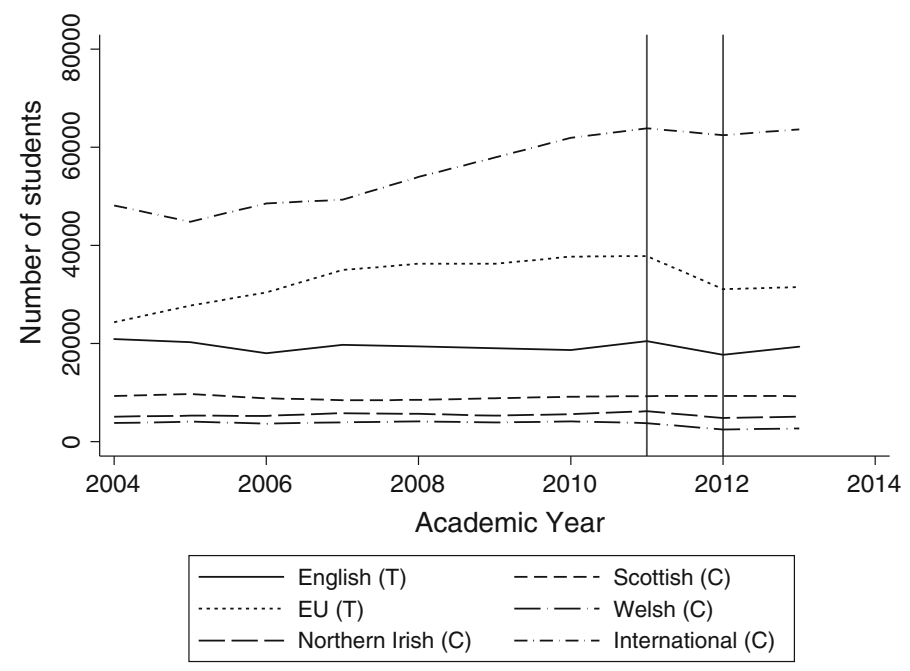

Fig. 3 Total amount of students studying outside their domicile region. Source Own calculations based on HESA data

domicile region (e.g. English students studying in Wales). Naturally, the figure for international students is the highest (since none of these are studying at home), but for the other groups, we see more or less continuous lines. This is understandable from the perspective of policy, since students cannot easily change the fee-regime by moving to another country of the United Kingdom. In order to qualify for lower fees, students would have to move out of England 3 years before applying to university. This is rather unlikely to happen in large numbers, since the cost of moving an entire family will probably be higher than the costs of fees. ${ }^{11}$

\subsection{Anticipation Effects in Enrolment Decisions}

It is a typical problem in the public policy literature that people may anticipate policy changes and change their behaviour. The problem in this case is that the student cohort of 2011/12 may have already foreseen that tuition fees would be raised by the academic year 2012/13. Some students that would have normally enrolled in academic year 2012/13 could have enrolled in the previous academic year to 'escape' the higher fees. The Browne review that announced an increase in fees was indeed published a few months before the enrolment deadlines of the

\footnotetext{
${ }^{11}$ There have been stories of 'fee-refugees', however, the cost of moving to a foreign country may also be higher than paying the fees. http://www.theguardian.com/education/mortarboard/2012/aug/ 24/fee-refugees-disappointed.
} 
2011/12 academic year. Students who would otherwise defer their enrolment to the next year, or older students could therefore decide to enrol in the academic year 2011/12. Any analysis of the discontinuity between academic years 2011/12 and 2012/13 may therefore overestimate the causal effect of the fees. In the empirical section, therefore, I will systematically compare enrolment in the academic year 2010/11 with enrolment in academic year 2013/14.

\section{Data and Results}

Research on social inequality in education is usually based on general population surveys (Breen et al. 2009; Shavit and Blossfeld 1993) also in the context of privatisation reforms (Torche 2005). Such data allow researchers to compare the social background of students and graduates to the social background in the general population. Ideally, I would use a longitudinal survey of the general population to assess whether enrolments in higher education changed before and after the marketisation. For the research questions asked here, such data either is not available (yet), does not provide enough detail on the social background of the students, or suffers from both of these problems. ${ }^{12}$

Instead, data on student enrolments are drawn from the Higher Education Statistics Agency (HESA), ${ }^{13}$ which collects register data ${ }^{14}$ about students in nearly all universities in the United Kingdom. ${ }^{15}$ This data is collected at the individual level, and contains information about the students' age, year of study, and social background and ethnicity. Information on social class is only collected here for students younger than 21 years old, following the 8-class National Statistics Social Economic Classification (in turn, this is based on the EGP class scheme). Data in these classes have been collapsed into 4 classes (Service class, Middle Class, Working Class and Unemployed), allowing for a hierarchical comparison.

In each of the models presented below, the dependent variable is the 'number of new enrolments' (Y for region $i$ and time-period $j$ ), while the independent variables are 'Treatment', which is a dummy indicating whether the region is treated or

\footnotetext{
${ }^{12}$ The 'Understanding Society' survey comes closest, with a sample of 40,000 households who are followed over time. The number of university enrolments is very limited (typically around 200 per wave), implying that years of enrolment would have to be collapsed together to get enough individuals in each cell. Moreover, data for 2012/13 are not yet available at the time of writing.

${ }^{13} \mathrm{HESA}$ does not accept responsibility for any inferences or conclusions derived from the data by third parties.

${ }^{14}$ Standard errors and t-statistics lose their usual meaning in this context, since this is not a random sample. These will be provided below, in any case, to give an idea of the variance of the effect. Moreover, these may be relevant if we think of a 'super-population' of higher education systems in which marketisation may occur in the future.

${ }^{15}$ Data is provided here for 158 universities, out of a total of approximately 162 universities in the United Kingdom.
} 
control, and 'Post-period', which is a dummy indicating the time pre- or post-treatment as well as the 'interaction between treatment and post-period' as the difference-in-differences estimator. This model looks as follows, and is the same for each analysis below:

$$
Y_{i j}=b_{1} \text { Treatment }+b_{2} \text { Postperiod }+b_{3} \text { Treatment } * \text { Postperiod }+e_{i j}
$$

Results are presented below in four sections, namely (1) general effects on enrolments in universities, (2) effects on enrolments of students from different age groups, (3) effects on enrolments of students from different social classes, and (4) effects on different ethnic groups.

It should be noted here already that the major disadvantage of using only student data is that they do not allow me to compare the social background of the students to the social background of the general population. The consequence is that I have to restrict my dependent variable to the number of first-year enrolments in each group of interest before and after the policy change. The assumption that this analysis makes is that the social composition of the population did not change in the observed time-period (between academic year 2010/11 and 2013/14). This analysis cannot be done at the individual level, but at the regional level at which policies are made (all individuals are enrolled at university, so there is no variation in enrolment propensity). Thus, while the data are collected at the individual level, they have been collapsed at the domicile region level (the treatment and control groups discussed above). For each analysis, I have carried out three main robustness checks: using more years for the pre- and post-period, using 'new enrolments as a percentage of the population' as a dependent variable, and using Poisson regression models.

Another disadvantage is that 'enrolments' do not take into account the differences between applicants and enrolments (assuming that the former are higher than the latter). Enrolment data thus provide an incomplete picture of student demand. On the other hand, enrolment figures may better represent actual demand for higher education, since applications may come from people who might not have the necessary qualifications to study at university. I will come back to this point in the discussion of the results.

\subsection{First Year Enrolment}

Table 4 shows the effects of the marketisation on general enrolment trends (coefficients in column 1-M1). The causal effect is highlighted in bold (the interaction between treated region and post-period). For the average treatment region, the number of students declined by just over 8000 students after the reforms. This is equivalent to a $15 \%$ decrease of student numbers compared to the pre-treatment period. From a counterfactual perspective, this means that there were around 72,000 students who would have enrolled in England if the reforms had not been introduced. Figure 4 presents a graph of observed and counterfactual trends in the treatment and control regions. 
Table 4 Coefficients for general models where dependent variable is count of first year enrolments, and the unit of analysis is the region of domicile

\begin{tabular}{l|l|l|l|l}
\hline & M1 & M2 & M3 & M4 \\
\hline $\begin{array}{l}\text { Dependent } \\
\text { variable }\end{array}$ & $\begin{array}{l}\text { New } \\
\text { enrolments }\end{array}$ & $\begin{array}{l}\text { New } \\
\text { enrolments } \\
\text { (all years) }\end{array}$ & $\begin{array}{l}\text { New enrolments as \% } \\
\text { of 18-24 year old } \\
\text { population }\end{array}$ & $\begin{array}{l}\text { New } \\
\text { enrolments } \\
\text { (Poisson } \\
\text { regression) }\end{array}$ \\
\hline \multirow{2}{*}{$\begin{array}{l}\text { Treatment } \\
\text { group }\end{array}$} & $38,310^{* *}$ & $39,550^{* * *}$ & -0.01 & $1.219^{* * *}$ \\
\cline { 2 - 5 } & $(10,305)$ & $(10,115)$ & $(0.009)$ & 0.003 \\
\hline Post-period & -770 & -295 & -0.006 & $-0.049 * * *$ \\
\cline { 2 - 5 } & $(720)$ & $(1150)$ & $(0.005)$ & 0.003 \\
\hline $\begin{array}{l}\text { Treated in } \\
\text { post-period } \\
\text { (causal effect) }\end{array}$ & $-8030 * * *$ & $-9915^{* * *}$ & -0.012 & $-0.127 * * *$ \\
\cline { 2 - 5 } Constant & $(1510)$ & $(2090)$ & $(0.006)$ & 0.004 \\
\hline \multirow{2}{*}{ 2 } & $16,075 *$ & $15,460^{*}$ & $0.121 * * *$ & $9.685^{* * *}$ \\
\hline bic & $(5755)$ & $(5515)$ & $(0.007)$ & 0.002 \\
\hline $\mathrm{N}$ & 0.396 & 0.415 & 0.377 & 738580.368 \\
\hline
\end{tabular}

Note Standard errors in parentheses, clustered at the domicile level. Estimates and standard errors in model 1 and 2 are rounded to nearest 5 to preserve anonymity. Source Own calculations based on HESA data. Significance levels $* p<0.05, * * p<0.01, * * * p<0.001$

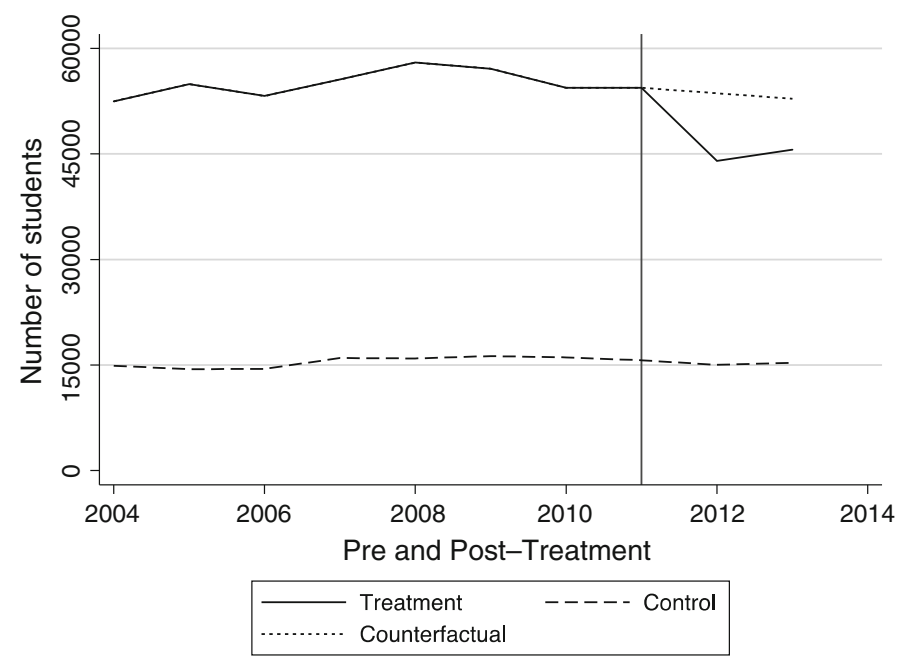

Fig. 4 Observed and counterfactual trends in university enrolments in treatment and control regions. Predicted effects (based on predicted probabilities) for counterfactual after treatment. Source Own calculations based on HESA data 
It is clear from Fig. 3 that there has been a substantial drop in enrolment following marketisation, which may prove costly for English society on the long run. This figure may surprise some, since earlier releases (UCAS 2012) reported the reduction in acceptances to be substantially smaller (around $5.5 \%$ ). There could be two potential explanations for this divergence. First, UCAS does not record enrolments as such, meaning that students may still have decided not to enrol after being accepted. Secondly, UCAS seems to report new enrolments in general, while the estimation here is based on new enrolments in undergraduate programmes (i.e. those for which fees were raised). Another point is that the finding here is in line with many earlier findings on the price-responsiveness of students mentioned earlier.

The three columns to the right (M2-M4) provide various robustness checks on these results. The second column (M2) shows that the results also hold when all previous years for which I have data are used as controls (2004-2011). The effect is now bigger in terms of the point estimate $(-9915)$ as well as in percentage terms (18\%). The third column of coefficients (M3) shows that the decline in student numbers holds when checking for changes in the population of young people. This specification uses the number of new enrolments as a proportion of the total 18 24 year old population (based on yearly population estimates from the Office for National Statistics). ${ }^{16}$ The effect size is obviously much smaller, but comparable to the other effect sizes in terms of percentage change, namely $-16 \%$. The fourth column (M4) shows a Poisson regression with the same specification. Poisson models are developed to analyse count-data (such as in this case, the number of students). This model yields the same size and direction of the effect $(-18 \%$ in terms of marginal effect), and is also statistically significant.

\subsection{Enrolment for Different Age Groups}

As outlined in the section on expectations, different groups of students may face different costs and benefits from attending higher education. Table 5 shows the effects broken down for different age groups (full regression results in Appendix 1). While school-leavers (16/18 years old) are almost unaffected by the reforms, all older students are strongly affected.

The results indicate that students from these different age groups have reacted differently to the marketisation process. While younger students seem not to have reacted at all, the picture is quite different for older students. By far the biggest effect is visible for students who are older than 30 , for which we observe a decrease by about $1 / 3$ in enrolments.

\footnotetext{
${ }^{16}$ This has become the standardized base population used in studies of student demand. In effect, the 18-24 year old population is seen as the population that is most likely to enroll. See Leslie and Brinkman (1987) in the references for a discussion of this base.
} 
Table 5 Effect sizes for different age groups

\begin{tabular}{l|l|l}
\hline Age group & Absolute change in treated regions & Percentage change $(\%)$ \\
\hline 16 to 18 years & -135 students & -1 \\
\hline $19 / 21$ years & -1995 students & -12 \\
\hline $22 / 30$ years old & -2070 students & -23 \\
\hline 30 and older & -3805 students & -34 \\
\hline
\end{tabular}

Note The unit of analysis is the region of domicile (standard errors in parentheses, clustered at the domicile level). Estimates and standard errors in model 1 and 2 are rounded to nearest 5 to preserve anonymity. Source Own calculations based on HESA data. Full regression output in Appendix 1

Table 6 Effect sizes for different social classes

\begin{tabular}{l|l|l}
\hline Parental social class & Absolute change in treated regions & Percentage change $(\%)$ \\
\hline Service class & -535 & -3 \\
\hline Middle class & -125 & -2 \\
\hline Working class & +520 & +7 \\
\hline Unemployed & +10 & +19
\end{tabular}

Note Parental social class is recorded only for students under 22 years of age, domiciled in the United Kingdom. The unit of analysis is the region of domicile (standard errors in parentheses, clustered at the domicile level). Estimates and standard errors in model 1 and 2 are rounded to nearest 5 to preserve anonymity. Source Own calculations based on HESA data. Full regression output in Appendix 1

\subsection{Enrolment for Different Social Classes}

As argued above, one of the main questions in the debate was whether inequality between students would increase. Table 6 presents a summary of the results for the different social classes (full regression tables in Appendix 1). Since it is likely that older students are more prominently from working class backgrounds, it should be noted here already that these results are probably biased (I will come back to this point in the discussion). The estimates indicate a heterogeneous effect of the tuition fees.

While there is a small decline for upper and middle class students, there is an increase in students with parents in the working class or among the unemployed. Further investigation of the data showed that the results also hold if we compare the class background of 18 year olds versus 21 year olds (results not presented here due to space limitations). The results hold when using all years as a control. Using proportions of students in each social class as a proportion of total population in the same social class (using census data from 2011) does not change the estimates. When using Poisson regression, however, the effect size becomes statistically non-significant. This means that some caution is warranted in interpreting these changes as a decrease in inequality (note, however, that these are register data, and thus statistical significance does not carry its conventional meaning). 
Table 7 Effect sizes for different ethnic groups

\begin{tabular}{l|l|l}
\hline Ethnicity & Absolute change in treated regions & Percentage change (\%) \\
\hline White & -4895 students & -10 \\
\hline Black or Black British & -380 students & -8 \\
\hline Asian or Asian British & -130 students & -3 \\
\hline Mixed & -75 students & -4 \\
\hline Other & -190 students & -8 \\
\hline
\end{tabular}

Note Ethnic group is recorded only for students domiciled in the United Kingdom. The unit of analysis is the region of domicile (standard errors in parentheses, clustered at the domicile level). Estimates and standard errors in model 1 and 2 are rounded to nearest 5 to preserve anonymity. Source Own calculations based on HESA data. Full regression output in Appendix 1

\subsection{Enrolment for Different Ethnic Groups}

One less investigated area of inequality in British higher education is ethnicity. Table 7 presents the results of the analysis for the largest ethnic groups (full regression results in Appendix 1). The table makes clear that all ethnic groups are negatively affected by the 2012 reforms, although to different extents. Whites, blacks and others face the strongest decreases (ranging between 8 and $10 \%$ ). Asians (including Indian British, Pakistaki British and Bangladeshi British) and mixed groups face a smaller decline (between 3 and $4 \%$ ).

While some may interpret these effects as a slight decrease in inequality between whites and other ethnic groups, caution is warranted. As Table 3 showed, whites make up more than $70 \%$ of all students in English universities, and over $90 \%$ of students in the control regions. Even after the reforms, whites are still by far the dominant group in all British universities. Rather, we can conclude from this the 2012 reforms did not exacerbate the existing inequalities between ethnic groups in English universities.

\section{Discussion and Conclusion}

This paper has provided a first analysis of how the 2012/13 reforms of the English higher education system have affected student enrolments. It has investigated four main effects, namely, on general enrolment patterns, on enrolment patterns of specific age groups, on different social classes and different ethnic groups. It has found that enrolments have declined substantially after the marketisation, particularly for older students and those from the middle and service class.

In terms of enrolment trends, the results are on the side of the pessimists. There has been a serious drop in enrolments following the marketisation reforms. The results indicate also that young and older students respond differently to marketisation. Whereas young people's decisions to go to university are almost unaffected, the decisions of older people are negatively affected. This may be a representation 
of different incentive structures facing younger and older students. The higher price may be driving older students off the market. If lifelong learning remains a policy goal, then this may require a policy response. Little is still known about the characteristics of older students, and more research would be needed to fill this gap.

In terms of social inequality, however, the evidence seems to point towards the optimist view. But we have to interpret this finding with some caution. There has been a drop in enrolments from the service class and middle class, while we can observe a small increase from working class or unemployed backgrounds. Moreover, white students were slightly more affected than other ethnic groups. This could point to the success of policies to shield lower income students from the higher prices (i.e. the extensive loans and grants programme). However, it may also be that students from lower social classes and non-whites are more strongly selected on unobserved traits (ability, motivation). As mentioned earlier, it is also quite likely that there are more working class students in the older age groups. Since the drop in enrolment for these older groups is much higher than for younger students, it is still possible that social inequality has remained stable (or has increased). Moreover, service class students are still strongly over-represented.

The question remains why different groups respond differently to marketisation. While this paper has not investigated the decision-making mechanisms of students, a number of candidate explanations are offered by the theory. Older students may perceive that they face both higher costs and lower benefits. While the financial cost is the same, older students may perceive the costs as higher due to added social costs (giving up a job, family life, etc.). They may also more negatively assess their chances of reaping benefits from studying in terms of labour market returns. This makes their overall assessment of risks higher, and therefore lower older students' propensity to enrol at university. Future research on the micro-mechanisms of student choices could clarify these questions.

These results may be sobering for both optimistic and pessimistic sides of the debate. As many countries are considering to increase fees or to introduce other market mechanisms, they may realise that this may come at a cost. Higher fees may deter substantial numbers of students, and particularly affect older students. On the other hand, the results make clear that the marketisation-particularly if combined with student support mechanisms - will not necessarily affect class inequality or inequality between ethnic groups. While future research may shed further light on these questions, these findings will hopefully lead to a more informed reflection on the role of tuition fees and student support in (higher) education.

Open Access This chapter is distributed under the terms of the Creative Commons Attribution Noncommercial License, which permits any noncommercial use, distribution, and reproduction in any medium, provided the original author(s) and source are credited. 


\section{Appendix 1: Full Regression Results for Age Groups, Parental Social Classes and Ethnic Groups}

Age Groups. Coefficients for models for specific age-groups where dependent variable is count of first year enrolments, and the unit of analysis is the region of domicile (standard errors in parentheses, clustered at the domicile level). Estimates and standard errors rounded to the nearest 5 to preserve anonymity.

\begin{tabular}{l|l|l|l|l}
\hline & $\begin{array}{l}16 \text { to } \\
18 \text { years }\end{array}$ & $19 / 21$ years & $\begin{array}{l}22 / 30 \text { years } \\
\text { old }\end{array}$ & $\begin{array}{l}30 \text { and } \\
\text { older }\end{array}$ \\
\hline \multirow{2}{*}{ Dependent variable } & $\begin{array}{l}\text { New } \\
\text { enrolments }\end{array}$ & $\begin{array}{l}\text { New } \\
\text { enrolments }\end{array}$ & $\begin{array}{l}\text { New } \\
\text { enrolments }\end{array}$ & $\begin{array}{l}\text { New } \\
\text { enrolments }\end{array}$ \\
\hline \multirow{2}{*}{ Treatment group } & $9730^{* *}$ & $9280^{* *}$ & $5380^{* *}$ & $7830^{* * *}$ \\
\cline { 2 - 5 } & $(2630)$ & $(2620)$ & $(1580)$ & $(2040)$ \\
\hline Post-period & $250^{*}$ & -10 & $-365^{* *}$ & -305 \\
\cline { 2 - 5 } & $(120)$ & $(110)$ & $(125)$ & $(200)$ \\
\hline \multirow{2}{*}{$\begin{array}{l}\text { Treated in post-period } \\
\text { causal effect) }\end{array}$} & -330 & $-2480^{* * *}$ & $-2005^{* * *}$ & $-3420^{* * *}$ \\
\cline { 2 - 5 } Constant & $(200)$ & $(480)$ & $(390)$ & $(660)$ \\
\hline r2 & $4000^{*}$ & $3840 *$ & $2655^{* *}$ & 2515 \\
\cline { 2 - 5 } & $(1515)$ & $(1400)$ & $(930)$ & $(1215)$ \\
\hline bic & 0.4 & 0.361 & 0.354 & 0.404 \\
\hline $\mathrm{N}$ & 903 & 898 & 849 & 871 \\
\hline
\end{tabular}

Source Own calculations based on HESA data. Significance levels $* p<0.05$, ** $p<0.01$, $* * * p<0.001$

Social Classes. Coefficients for models for specific social classes where dependent variable is count of first year enrolments, and the unit of analysis is the region of domicile (standard errors in parentheses, clustered at the domicile level).

\begin{tabular}{l|l|l|l|l}
\hline & $\begin{array}{l}\text { Service } \\
\text { class }\end{array}$ & $\begin{array}{l}\text { Middle } \\
\text { class }\end{array}$ & $\begin{array}{l}\text { Working } \\
\text { class }\end{array}$ & Unemployed \\
\hline Dependent variable & $\begin{array}{l}\text { New } \\
\text { enrolments }\end{array}$ & $\begin{array}{l}\text { New } \\
\text { enrolments }\end{array}$ & $\begin{array}{l}\text { New } \\
\text { enrolments }\end{array}$ & $\begin{array}{l}\text { New } \\
\text { enrolments }\end{array}$ \\
\hline Treatment group & $7810^{*}$ & $2520^{*}$ & $3210^{*}$ & 20 \\
\cline { 2 - 5 } & $(3380)$ & $(1030)$ & $(1065)$ & $(20)$ \\
\hline Post-period & -60 & -95 & 20 & 60 \\
\cline { 2 - 5 } & $(170)$ & $(50)$ & $(80)$ & $(40)$ \\
\hline \multirow{2}{*}{$\begin{array}{l}\text { Treated in post-period } \\
\text { causal effect) }\end{array}$} & -535 & -130 & $520^{*}$ & 10 \\
\hline Constant & $(275)$ & $(115)$ & $(215)$ & $(50)$ \\
\hline & $8890^{* *}$ & $3700^{* * *}$ & $3860^{* * *}$ & $35^{*}$ \\
\cline { 2 - 5 } & $(2285)$ & 440 & $(505)$ & $(15)$ \\
\hline
\end{tabular}


(continued)

\begin{tabular}{l|l|l|l|l}
\hline & $\begin{array}{l}\text { Service } \\
\text { class }\end{array}$ & $\begin{array}{l}\text { Middle } \\
\text { class }\end{array}$ & $\begin{array}{l}\text { Working } \\
\text { class }\end{array}$ & Unemployed \\
\hline $\mathrm{r} 2$ & 0.237 & 0.196 & 0.292 & 0.204 \\
\hline $\mathrm{bic}$ & 497 & 449 & 454 & 284 \\
\hline $\mathrm{N}$ & 24 & 24 & 24 & 24 \\
\hline
\end{tabular}

Source Own calculations based on HESA data. Significance levels $* p<0.05, * * p<0.01$, $* * * p<0.001$

Ethnic Groups. Coefficients for models for specific social classes where dependent variable is count of first year enrolments, and the unit of analysis is the region of domicile (standard errors in parentheses, clustered at the domicile level).

\begin{tabular}{l|l|l|l|l|l}
\hline & Whites & Blacks & $\begin{array}{l}\text { Asian } \\
\text { (British) }\end{array}$ & Mixed & Other \\
\hline $\begin{array}{l}\text { Dependent } \\
\text { variable }\end{array}$ & $\begin{array}{l}\text { New } \\
\text { enrolments }\end{array}$ & $\begin{array}{l}\text { New } \\
\text { enrolments }\end{array}$ & $\begin{array}{l}\text { New } \\
\text { enrolments }\end{array}$ & $\begin{array}{l}\text { New } \\
\text { enrolments }\end{array}$ & $\begin{array}{l}\text { New } \\
\text { enrolments }\end{array}$ \\
\hline Treatment group & 11,390 & 4595 & $4075^{*}$ & $1670^{*}$ & 1840 \\
\cline { 2 - 6 } & $(9135)$ & $(2985)$ & $(1445)$ & $(695)$ & $(1220)$ \\
\hline Post-period & -3630 & $14^{* *}$ & -5 & $35^{*}$ & -75 \\
\cline { 2 - 6 } & $(2005)$ & $(4)$ & $(20)$ & $(15)$ & $(55)$ \\
\hline \multirow{2}{*}{$\begin{array}{l}\text { Treated in } \\
\text { post-period }\end{array}$} & -4895 & -380 & -130 & -75 & -190 \\
\hline causal effect) & $(2260)$ & $(335)$ & $(165)$ & $(55)$ & $(205)$ \\
\hline Constant & $35,280^{* * *}$ & $334 *$ & $574 *$ & $427 *$ & $540 *$ \\
\hline r2 & $(7805)$ & $(145)$ & $(225)$ & $(140)$ & $(185)$ \\
\hline bic & 0.18 & 0.079 & 0.226 & 0.175 & 0.08 \\
\hline $\mathrm{N}$ & 530 & 503 & 468 & 433 & 458 \\
\hline
\end{tabular}

Source Own calculations based on HESA data. Significance levels $* p<0.05, * * p<0.01$, $* * * p<0.001$

\section{References}

Angrist, J. D., \& Pischke, J. S. (2008). Mostly harmless econometrics: An Empiricist's Companion. Princeton: Princeton University Press.

Ansell, B. W. (2010). From the ballot to the blackboard. The redistributive political economy of education. New York: Cambridge University Press (Cambridge studies in comparative politics).

Becker, G. S. (1993). Human capital. A theoretical and empirical analysis, with special reference to education (3rd ed.). Chicago: The University of Chicago Press.

Boliver, V. (2011). Expansion, differentiation, and the persistence of social class inequalities in British higher education. Higher Education, 61(3), 229-242. 
Breen, R., \& Goldthorpe, J. (1997). Explaining educational differentials: Towards a formal rational action theory. Rationality and Society, 9, 275-305.

Breen, R., Luijkx, R., Müller, W., \& Pollak, R. (2009). Nonpersistent inequality in educational attainment: Evidence from eight European Countries: Evidence from eight European Countries. American Journal of Sociology, 114(5), 1475-1521. doi:10.1086/595951.

Brown, R. (2013). Everything for Sale? The Marketisation of UK Higher Education. London: Routledge.

Cameron, V. S., \& Heckman, J. J. (1998). Life cycle schooling and dynamic selection bias: Models and evidence for five cohorts of American males. Journal of Political Economy, 106, 262-333.

Card, D., \& Krueger, A. B. (1994). Minimum wages and employment: A case study of the fast food industry in New Jersey and Pennsylvania. American Economic Review, 84(4), 772-793.

Carneiro, Pedro, \& Heckman, J. J. (2002). The evidence on credit constraints in post-secondary schooling. Economic Journal, 112(482), 705-734.

Chowdry, H., Dearden, L., Goodman, A., \& Jin, W. (2012). The distributional impact of the 2012 13 higher education funding reforms in England. Fiscal Studies, 33(2), 211-236.

Coelli, M. B. (2009). Tuition fees and equality of University Enrolment. Canadian Journal of Economics, 42(3), 1073-1099.

College Board. (2014). The. 2014. Trends in College Pricing. New York: The College Board.

Dearden, L., Fitzsimons, E., Goodman, A., \& Kaplan, G. (2008). Higher education funding reforms in England: The distributional effects and the shifting balance of costs. The Economic Journal, 118(526), F100-F125. doi:10.1111/j.1468-0297.2007.02118.x.

Dearden, L., Fitzsimons, E., \& Wyness, G. (2011). The Impact of Tuition Fees and Support on University Participation in the UK. London: IFS Working Paper, IFS.

Dynarski, S. M. (2003). Does aid matter? Measuring the effect of student aid on college attendance and completion. American Economic Review, 93(1), 279-288. doi:10.1257/ 000282803321455287.

Ellwood, D. T., \& Kane, T. J. (2000). Who is getting a college education? Family Background and the Growing Gaps in Enrollment. In S. Danziger \&. J. Waldfogel (Eds.), Securing the future: Investing in children from birth to college. New York: Russell Sage Foundation.

Eurydice, (2014). National Student Fee and Support Systems in European Higher Education. Brussels: Eurydice.

Gerber, T. P., \& Cheung, S. Y. (2008). Horizontal stratification in postsecondary education: forms, explanations, and implications. Annual Review of Sociology, 34(1), 299-318. doi:10.1146/ annurev.soc.34.040507.134604.

Heller, D. E. (1997). Student price response in higher education: an update to Leslie and Brinkman. Journal of Higher Education, 68(6), 624-659.

Hillmert, S., \& Jacobs, M. (2003). Social inequality in higher education. Is vocational training a pathway leading to or away from University? European Sociological Review, 19(3), 319-334.

Hübner, M. (2012). Do tuition fees affect enrollment behavior? Evidence from a 'natural expe-riment' in Germany. Economics of Education Review(31), 949-960.

Kane, T. J (1995). Rising Public College Tuition and College Entry: How Well Do Public Subsidies Promote Access to College?.

Kane, T. J. (2004). College-going and Inequality. In Kathryn, M. Neckerman, (Ed.), Social inequality. New York: Russell Sage Foundation.

Leslie, L. L., \& Brinkman, P. T. (1987). Student price response in higher education: the student demand studies. The Journal of Higher Education, 58(2), 181-204.

McGettigan, A. (2013). The Great University Gamble. London: Pluto Press.

McPherson, M. S., \& Schapiro, M. O. (1991). Keeping College Affordable: Government and Educational Opportunity. Washington, D.C.: The Brookings Institution.

OECD. (2014). Education at a Glance. Paris: Organisation for Economic Cooperation and Development. 
Orr, D., Gwosc, G., \& Netz, N. (2011). Social and Economic Conditions of Student Life in Europe. Synopsis of Indicators Final Report. Eurostudent IV. Bielefeld: W. Bertelsmann Verlag.

Pratt, J. W. (1964). Risk aversion in the small and in the large. Econometrica, 32(1-2), 122-136.

Schofer, E., \& Meyer, J. W. (2005). The worldwide expansion of higher education. American Sociological Review, 70(6), 898-920.

Shavit, Y., \& Blossfeld, H. P. (1993). Persistent inequality: Changing educational attainment in thirteen countries. Boulder, Colo: Westview Press.

Shavit, Y., Arum, R., \& Gamoran, A. (Eds.). (2007). Stratification in higher education. A comparative study. Stanford, CA: Stanford University Press. (Studies in social inequality). Torche, F. (2005). Privatization reform and inequality of educational opportunity: the case of chile. Sociology of Education, 78(4), 316-343. doi:10.1177/003804070507800403.

UCAS. (2012). End of Cycle Report. 2012. Cheltenham: UCAS. 